\title{
The Effect of Workplace Discipline and Working Conditions on Teacher Performance at MTS Negeri 2 OKU Timur
}

\author{
Lisa Selpiyani ${ }^{1 *}$, Bukman Lian ${ }^{1}$, Alhadi Yan Putra ${ }^{1}$ \\ ${ }^{1}$ Universitas PGRI Palembang, Indonesia \\ "Corresponding author.Email: lisamuallimin7@gmail.com
}

\begin{abstract}
The purpose of this research is to determine the effect of work discipline on teacher performance, the effect of the working environment on teacher performance, and the effect of work discipline and the working environment together on teacher performance. The study was carried out at MTs Negeri 2 OKU Timur, Cempaka District, East OKU Regency. This study employs a descriptive method with a quantitative approach that is supported by a literature review. Using the SPSS version 25 program, data testing techniques used in this study included regression and correlation, determination, partial, and simultaneous tests. 1) There is a positive and significant effect of work discipline on teacher performance at MTs Negeri 2 OKU Timur, namely 53, 1 percent, according to the findings of this study. 2) There is a positive and significant influence on work discipline and work environment together on teacher performance at MTs Negeri 2 OKU Timur, which is 11.3 percent, and 3) there is a positive and significant influence on work discipline and work environment together on teacher performance at MTs Negeri 2 East OKU, which is 53.1 percent. With the conclusion that work discipline and work environment have a significant effect on teacher performance at MTs Negeri 2 OKU Timur.
\end{abstract}

Keywords: Workplace Discipline, Working Conditions, and Teacher Performance

\section{INTRODUCTION}

Education is a deliberate effort to prepare students for their future roles through guidance, teaching, and/or training activities. [1]

with no intention of understating the contribution of the other components, the education staff or teacher component is one of the most essential factors in determining the quality of students [2] Teachers are the spearhead who carry out the learning process in schools, so the quality and number of teachers need to be improved and developed according to current and future needs. The application of teacher development in schools is the personal development of teachers to explore their potential. A school that is considered good and is considered quality if the students have high achievement. The role of the teacher in managing the teaching components used in the teaching and learning process for which they are responsible is frequently viewed as determining the quality of education and graduates. For the teacher's duties and responsibilities to be properly carried out, the teacher must have a good performance. Teacher performance is always the center of attention [3].
From the observations of researchers at the school selected as the object of research, namely MTs Negeri 2 OKU Timur, it was found that the performance of teachers could not be said to have shown maximum results. This can be seen from several phenomena that the researchers found, among others (1) learning planning has not been made optimally because lesson plans and learning tools still exist using copy-paste culture; (2) in the implementation of learning, some teachers still dominantly use the lecture method; (3) in the implementation of learning, some teachers have not used various media and learning resources. Other problems that the researchers found were: first, the teacher's role was not maximal in escorting students to achieve achievements in certain activities.

The second is the performance of teachers who have not shown the professional competence of an educator, this can be seen from the discipline of teachers who often leave school hours for certain reasons, for example doing additional tasks that are not the main or main task as teachers and there are still teachers who are civil servants coming to school. it only fits during the lesson hours and comes home early after the teaching assignment is finished even though the working hours have not finished which is certainly against the employment regulations which require them to work at 
school for 40 hours/week Teachers' poor performance can be influenced by factors both internal and external to the individual teacher. Performance is influenced by a variety of factors, including work environment, organizational culture, leadership and work motivation, work discipline, salary, job satisfaction, and others, according to [4].

According to the above viewpoint, work discipline is one of the factors that can influence teacher performance. [5] defines discipline as "a person's awareness and willingness to obey all company regulations and prevailing social norms." While [6] contends that work discipline is a person's ability to consistently, persistently persevere, and work by applicable rules without violating predetermined rules.

Thus, discipline is the attitude of adhering to and obeying all organizational rules when performing work in order to achieve the desired results. The existence of rules or regulations is related to discipline. As a result, a disciplined teacher is one who follows all of the rules established by the organization as well as applicable social norms. A person's sense of responsibility for the tasks assigned to him is reflected in his sense of discipline.

According to Government Regulation [7], concerning Civil Servant Discipline Regulations, work discipline is defined as civil servants' ability to comply with obligations and avoid prohibitions that have been determined in statutory regulations and/or official regulations, which if not obeyed or violated will result in disciplinary action. That is, work discipline is the willingness to follow the rules, whether written or unwritten. With discipline, it is possible to increase work passion, morale, and support the achievement of planned goals. Because a good understanding of the discipline of the teacher can observe the rules and strategic steps in carrying out the teaching and learning process, high discipline will be able to build professional performance.

The work environment is another factor that influences performance. The teacher's work environment is the condition and working relationship of a teacher individually and in groups which includes: lighting, coloring, cleanliness, air exchange, security, noise (sound), workspace layout and work equipment, as well as work relations consisting of communication, cooperation, work atmosphere and attitude [8], The work environment for teachers is a scope or area in developing competence and knowledge, as well as the insights they have to help carry out work activities. In the end, it will improve the teacher's performance. Therefore, a good work environment participates in helping achieve the desired school goals by the existing vision and mission [8],

A good work environment can foster a positive working relationship among those who work in it. According to Mulyasa, to create a conducive work environment, at least two things are needed, namely the teacher himself and a good relationship between teachers and parents and the surrounding community [9], In line with this opinion, supportive working conditions are needed, namely a comfortable working environment for them. A good work environment will facilitate them to work better too. They prefer physical conditions that are not dangerous or comfortable. Besides that, most of them like a relatively close workplace [10],

In the implementation, it is often not as expected by the school, a bad work environment will affect individual teachers, so that the responsibility as an education provider is not optimal, starting from the work environment which concerns the physical condition of the school, for example, the comfort of the workspace and school infrastructure. as well as the work environment related to psychological conditions such as unpleasant feelings between teachers and leaders, of course, is thought to affect the performance of a teacher. As a phenomenon, the researchers found that hot classrooms in a school building located on the second floor caused students to often come in and out during class hours, especially during the last lesson. As a result, students are not enthusiastic to learn, This sometimes causes teachers to be lazy to enter the class at the last hour, so they only give assignments to students. Of course, if this is permitted, the teacher's performance will suffer as a result.

Based on the foregoing, the researcher believes it is necessary to carry out a study titled "The Effect of Work Discipline and Work Environment on Teacher Performance at MTs Negeri 2 OKU Timur."

\section{METHODS}

This study employs a quantitative descriptive method to examine the relationship between variables [19]. The variables examined in this study were as follows: Work Discipline (X1) Work Environment (X2), Work Discipline (X1) on performance. teacher (Y), work environment (X2) on teacher performance (Y), while testing the hypothesis together (simultaneously), namely work discipline (X1) and work environment (X2) on teacher performance (Y), then all data obtained processed and processed with quantitative analysis techniques.

The population is a generalization area consisting of objects or subjects with specific qualities and characteristics that researchers determine to study and then draw conclusions from (Sugiyono, 2018). The entire population is the research subject (Arikunto, 2010). The participants in this study were all teachers at MTs Negeri 2 OKU Timur, Cempaka District, East OKU Regency, totaling 40 people consisting of 35 female teachers and 5 male teachers.

Samples are some of the objects under study and are considered capable of representing the entire population and are taken using certain techniques. According to 
that "Research carried out on populations below 100 should be carried out by census, so that all members of the population are sampled all as subjects studied or as respondents providing information". As a result, the sampling technique used in this study was a census (total sampling) with the entire population as a sample, namely all teachers of MTs Negeri 2 OKU Timur totaling 40 people.

Documentation and questionnaires were used to collect data in this study. This study employs a questionnaire as an instrument to collect empirical data on the observed variables.

1. punctuality is an indicator of work discipline. 2 . Able to use and use equipment properly 3. Produce satisfying work 4. Follow predetermined work methods 5. Have high responsibility (Soejono in Firdousy, 2009).

The work environment is everything around the teacher which consists of 1). a physical work environment with indicators of lighting, coloring, air, cleanliness, noise, and safety. 2). a non-physical work environment with indicators of relationships with superiors and colleagues (Damayanti, 2018).

\section{RESULTS AND DISCUSSION}

This hypothesis testing is done by using regression and correlation techniques, while the correlation techniques used are statistical analysis of correlation and determination, regression coefficient ( $\mathrm{t}$-test), and multiple regression coefficients ( $\mathrm{F}$ test), which are processed using SPSS version 25 .

1. Hypothesis Testing of Work Discipline (X1) on performance $(\mathrm{Y})$

According to the table above, the significance value (sig.) of 0.000 is less than 0.05 , and the $t$ value is 6.565 with a value of a / $2=0.05 / 2=0.025$ with $\mathrm{df}=\mathrm{n}-2=$ $40-2=38$ so that the $t$ table value is 0.681 so that the $t$ value is $6.565>0.681$. It can be concluded that $\mathrm{H} 01$ is rejected and $\mathrm{Ha} 1$ is accepted, implying that work discipline has a significant impact on the performance of teachers at MTs Negeri 2 OKU Timur. The table below illustrates the impact of work discipline on teacher performance.

Table 1. Model Summary of Work Discipline $\left(\mathrm{X}_{1}\right)$ on Teacher Performance (Y)

\begin{tabular}{lcccr}
\hline Model & $\mathrm{R}$ & $\begin{array}{c}\mathrm{R} \\
\text { Square }\end{array}$ & $\begin{array}{c}\text { Adjusted } \\
\mathrm{R} \\
\text { Square }\end{array}$ & $\begin{array}{c}\text { Std. Error } \\
\text { of the } \\
\text { Estimate }\end{array}$ \\
\hline 1 & $.729^{\mathrm{a}}$ & 0.531 & 0.519 & 4.884 \\
\hline $\begin{array}{l}\text { a. Predictors: (Constant), Work Discipline, } \\
\text { teacher performance }\end{array}$
\end{tabular}

Based on the analysis results shown in column $\mathrm{R}$ of the table above, which means the correlation coefficient is known to be 0.729 , interpreted as a magnitude of the relationship of $72.9 \%$, and is included in the category of a close relationship between work discipline and teacher performance. In the column $\mathrm{R}$ square is interpreted as a determinant coefficient, it is obtained that the value of $R$ Square is 0.531 , meaning that the magnitude of the influence of work discipline on teacher performance at MTs Negeri 2 OKU Timur is $53.1 \%$ if the test is done individually.

2) Working Environment Hypothesis Testing $\left(\mathrm{X}_{2}\right)$ on performance (Y)

Table 2. Significance of the Effect of Organizational Commitment on Teacher Performance

\begin{tabular}{|c|c|c|c|c|c|}
\hline \multirow[b]{2}{*}{ Model } & \multicolumn{2}{|c|}{$\begin{array}{c}\text { Unstandardized } \\
\text { Coefficients } \\
\text { Std. }\end{array}$} & \multirow[t]{2}{*}{$\begin{array}{l}\text { Standardized } \\
\text { Coefficients }\end{array}$} & \multirow[b]{2}{*}{$\mathrm{t}$} & \multirow[b]{2}{*}{ Sig. } \\
\hline & B & $\begin{array}{l}\text { Std. } \\
\text { Error }\end{array}$ & & & \\
\hline $1 \quad$ (Constant) & 60.82 & 14.191 & & 4.286 & 0.000 \\
\hline $\begin{array}{l}\text { Working } \\
\text { Environment }\end{array}$ & 0.341 & 0.154 & 0.337 & 7.205 & 0.034 \\
\hline
\end{tabular}

a. Dependent Variable: Teacher Performance 
The significance value (sig.) of 0.034 is less than 0.05 , as shown in the table above. Given that the t value is 2.205>0.681, we can conclude that $\mathrm{H} 02$ is rejected and $\mathrm{H}$ a 2 is accepted, implying that the work environment has a significant impact on the performance of East OKU MTsN 2 teachers. Furthermore, the table below shows how much influence the work environment has on teacher performance.

Table 3. Model Summary of Working Environment $\left(\mathrm{X}_{2}\right)$ on Teacher Performance (Y)

\begin{tabular}{|c|c|c|c|c|}
\hline Model & $\mathrm{R}$ & $\begin{array}{c}\mathrm{R} \\
\text { Square }\end{array}$ & $\begin{array}{c}\text { Adjusted } \\
\text { R } \\
\text { Square }\end{array}$ & $\begin{array}{l}\text { Std. Error } \\
\text { of the } \\
\text { Estimate }\end{array}$ \\
\hline 1 & $.337^{\mathrm{a}}$ & 0.113 & 0.09 & 6.719 \\
\hline
\end{tabular}

The calculation of the determinant coefficient yielded an R-value of 0.337 , indicating that the relationship between work environment variables and performance is weak, while the R Square value of 0.113 indicates that the influence of the work environment on teacher performance at MTs Negeri 2 OKU Timur is $10.3 \%$ and the remaining $88.9 \%$.

3. Work Discipline (X1) and Work Environment (X2) Hypothesis Testing on Performance (Y)

Table 4. The results of multiple regression analysis Work

Discipline $\left(X_{1}\right)$ and Work Environment $\left(X_{2}\right)$ on Teacher

Performance (Y)

\begin{tabular}{|c|c|c|c|c|c|}
\hline Model & $\begin{array}{l}\text { Sum of } \\
\text { Squares }\end{array}$ & df & $\begin{array}{c}\text { Mean } \\
\text { Square }\end{array}$ & $\mathrm{F}$ & Sig. \\
\hline 1 Regression & 1028.393 & 2 & 514.196 & 20.986 & $.000^{\mathrm{b}}$ \\
\hline Residual & 906.582 & 37 & 24.502 & & \\
\hline Total & 1934.975 & 39 & & & \\
\hline
\end{tabular}

a. Dependent Variable: Teacher Performance

b. Predictors: (Constant), Work Discipline, Work

Environment

Based on the table, it is obtained that the probability value $(0.000)$ is smaller than the $\alpha$ value $(0.05)$, besides that the calculated $\mathrm{F}$ value of 20.986 is greater than $\mathrm{F}$ (0.05) $(2: 37)$ of 3.25 so that $\mathrm{Ha}$ is accepted. This means that there is a significant influence on work discipline and work environment together on teacher performance at MTs Negeri 2 OKU Timur. To find out the magnitude of the influence of work discipline and work environment can be seen in the table below.

Table 5. Model Summary of Work Environment $\left(\mathrm{X}_{2}\right)$ on Teacher Performance $(\mathrm{Y})$

\begin{tabular}{lcccr}
\hline Model & $\mathrm{R}$ & $\begin{array}{c}\mathrm{R} \\
\text { Square }\end{array}$ & $\begin{array}{c}\text { Adjusted } \\
\mathrm{R} \\
\text { Square }\end{array}$ & $\begin{array}{c}\text { Std. Error } \\
\text { of the } \\
\text { Estimate }\end{array}$ \\
\hline 1 & $.729^{\mathrm{a}}$ & 0.531 & 0.506 & 4.95 \\
\hline $\begin{array}{l}\text { a. Predictors: (Constant), Work Environment, } \\
\text { Teacher Performance }\end{array}$
\end{tabular}

The results of the calculation of the determinant coefficient in the table above show that the $\mathrm{R}$ square value is 0.531 so that it can be interpreted that the effect of work discipline and work environment together on teacher performance at MTs Negeri 2 OKU Timur is
$53.1 \%$, the remaining $46.9 \%$ is influenced by other factors. which are not included in the research variables. 


\section{CONCLUSION}

Based on the findings of descriptive research and data analysis, and hypothesis testing, the following conclusions can be drawn: 1) based on the partial test results, it is known that work discipline has a positive and significant influence on teacher performance at MTs Negeri 2 OKU Timur, which is 53.1 percent, with the remaining 46.9 percent influenced by factors other than the research variables; 2) it is known, based on the partial test results, that there is a positive and significant influence of the work environment on teacher performance at MTs Negeri 2 OKU Timur, namely $11.3 \%$, and the remaining $88.7 \%$ is influenced by other factors outside the research variables, and 3) based on the results of simultaneous testing, it is known that there is a positive and significant influence on work discipline and work environment together on teacher performance at MTs Negeri 2 OKU Timur, which is $53.1 \%$, and the remaining $46.9 \%$ is influenced by other factors outside the research variables.

\section{ACKNOWLEDGMENTS}

Our deepest gratitude goes to Teachers in MTs Negeri 2 OKU Timur, Chancellor of Palembang PGRI University, Director of the Postgraduate Program of PGRI Palembang University and the Education Management Study Program of PGRI Palembang University, who have supported us in doing this extraordinary thing. This project is funded independently. We also want to thank our Education Management friends who helped us a lot in a short time frame to complete this project.

\section{REFERENCES}

[1] Undang - Undang No.20 tahun 2003 [Law - Law No. 20 of 2003]. Diakses pada 25 juni 2020 pada https://peraturan.bpk.go.id/Home/Details/43920/uu -no-20-tahun-

2003\#: :text=Dalam\%20UU\%20ini\%20diatur\%20 mengenai,bahasa $\% 20$ pengantar $\% 3 \mathrm{~B} \% 20$ dan $\% 20 \mathrm{w}$ ajib\%20belajar

[2] Tamzil dkk. (2013). Pengaruh Kompetensi Profesional Guru, Motivasi Kerja, Dan Disiplin Kerja Terhadap Kinerja Guru Smk Negeri 2 Penajam Paser Utara [The Influence of Teacher Professional Competence, Work Motivation, and Work Discipline on Teacher Performance at Smk Negeri 2 Penajam Paser Utara]. Jurnal Geo Ekonomi, (117).

[3] Peraturan Mentri Pendidikan Nasional RI no. 16 tahun 2007. Jakarta Regulation of the Minister of National Education of the Republic of Indonesia no. 16 of 2007 [Regulation of the Minister of National Education of the Republic of Indonesia no. 16 of 2007]. Di akses pada 25 juni 2020 pada https://akhmadsudrajat.files.wordpress.com/2012/0 1/nomor-16-tahun-2007-dan-lampiran.pdf

[4] Siagian. (2013). Manajemen Sumber Daya Manusia [Human Resource Management]. Jakarta: Bumi Aksara.

[5] Hasibuan, M. (2011). Manajemen Sumber Daya Manusia [Human Resource Management]. Jakarta: Gunung Agung

[6] Aritonang, K. T. (2015). Kompensasi Kerja, dan Kinerja Guru SMP Kristen BPK Penabur Jakarta [Work Compensation, and Teacher Performance at BPK Penabur Jakarta Christian Middle School]. Jurnal Pendidikan Penabur - No.04/ Th.IV / Juli 2015.

[7] Peraturan Pemerintah nomor 53 tahun 2010 [Government Regulation number 53 of 2010]. diakses pada 25 juni 2020 pada http://sdm.ugm.ac.id/download/pp-no-53-tahun2010-tentang-disiplin-pns/

[8] Sari, D. P. (2018). Pengaruh Lingkungan Kerja Dan Disiplin Kerja Terhadap Kepuasan Kerja Guru Sekolah Menengah Kejuruan (Smk) Swasta Sekecamatan Pondok Aren [The Effect of Work Environment and Work Discipline on Job Satisfaction of Private Vocational High School Teachers in Pondok Aren District]. Jurnal Saintika Unpam. Vol. 1 No. 1 Juli 2018: 108 - 132.

[9] Mulyasa. (2013). Menjadi Kepala Sekolah Profesional [Becoming the Principal of a Professional School]. Bandung: Remaja Rosdakarya

[10] Usman, H. (2013). Manajemen Teori, Praktik, dan Riset Pendidikan [Management Theory, Practice, and Educational Research]. Jakarta: Bumi.Aksara.

[11] Mangkunegara. (2005). Manajemen Sumber Daya Manusia [Human Resource Management]. Bandung: PT Remaja Rosda Karya.

[12] Asyanti, S. (2018). Motivasi Kerja Kepala Sekolah [Work Motivation of Principals]. Pontianak: Yudha English Gallery. 